\title{
Performance of Winter Overseeded and Colorant-treated 'Tifway' Bermudagrass Receiving Weekly Irrigation and Simulated Traffic
}

\author{
Daniel Hargey, Benjamin Wherley ${ }^{1}$, Casey Reynolds, Richard White, \\ and Garrett Parker \\ Department of Soil and Crop Sciences, Texas A\&M University, College \\ Station, TX 77840
}

Additional index words. Green Lawnger, annual ryegrass, perennial ryegrass, water restrictions

Abstract. Municipal water restrictions across the southern and southwestern United States have created additional challenges for maintaining safe playing surfaces on recreational turf facilities. In recent years, many cities within these regions have begun to impose irrigation restrictions during winter months. Although winter overseeding has been regularly practiced in these areas, interest and use of colorants as an alternative to overseeding has grown due to decreasing water availability and budget concerns. Data on relative performance of colorant-treated vs. overseeded dormant turf would be of interest to turf managers, because colorants may be more cost-effective and require less water than winter overseeding. The objectives of this $\mathbf{2}$-year field study were to evaluate effects of winter treatments on performance (green cover, surface hardness, and soil moisture attributes), turfgrass injury resulting from simulated traffic, and spring transition of 'Tifway' bermudagrass (Cynodon dactylon L. $\times$ Cynodon transvaalensis Burtt-Davy) under a 1-day per week irrigation schedule. Treatments included 1) untreated bermudagrass, 2) fall colorant-treated bermudagrass, 3) perennial ryegrass (Lolium perenne L.) overseeded bermudagrass, and 4) turf-type annual ryegrass (Lolium multiflorum Lam.) overseeded bermudagrass. In both years, treatment differences were detected for percent green cover, soil volumetric water content (VWC), percent visual turfgrass injury, surface hardness, and percent bermudagrass transition. Percent green cover and visual turfgrass injury levels were similar between annual and perennial ryegrass in year 1, whereas loss of green cover and greater turfgrass injury were noted in annual ryegrass during the spring of year 2 . Residual benefits of fall colorant applications extended into February of year 1, but dissipated by late December of year 2, likely due to higher rainfall and warmer temperatures, which prevented full bermudagrass shoot dormancy. Overseeding reduced bermudagrass spring transition by up to $50 \%$ compared with untreated and colorant-treated plots. Fall colorant treatments did not accelerate bermudagrass transition compared with untreated plots. Results of the study demonstrate that environmental differences from season to season can impact the relative benefits derived from colorant applications, as well as the performance of annual and perennial ryegrass.

Winter overseeding of dormant bermudagrass (Cynodon dactylon sp.) athletic turf has been a common practice in the transition zone and southern United States. Winter overseeding provides an actively growing cool-season turfgrass stand that provides green color during winter dormancy as well as a functional recreational turf (Kopec and Umeda, 2014). However, maintaining a healthy stand

Received for publication 14 Dec. 2015. Accepted for publication 23 Mar. 2016.

This research was supported in part by Texas A\&M AgriLife Research.

We wish to acknowledge the generous support of the Turfgrass Research, Education, and Extension Endowment for supporting this research. We also would like to thank Dr. Lloyd Nelson for providing seed for the project.

${ }^{1}$ Corresponding author. E-mail: b-wherley@tamu. edu. entirely (City of Allen, TX, 2015; San Antonio Water System, 2013). Little is known regarding the potential for perennial ryegrass (Lolium perenne) or annual ryegrass (Lolium multiflorum Lam.) to persist under these infrequent irrigation schedules, and in light of increased water restrictions and reduced budgets, many turf managers have begun to explore turf colorants as an alternative to overseeding.

While perennial ryegrass has been the primary cool-season turfgrass used for winter overseeding of athletic turf, turf-type annual ryegrasses have been developed in recent years. These improved annual ryegrasses possess finer texture and improved color relative to older annual ryegrass cultivars such as Gulf and improved spring transition relative to perennial ryegrass. Nelson et al. (2005) compared the performance and quality of 'Axcella' and 'Panterra' annual ryegrass with perennial ryegrass cultivars and reported more rapid $(\approx 1$ month earlier) transition with turf-type annual ryegrasses, although turf quality was slightly inferior to perennial ryegrass. Trappe et al. (2012) compared traffic effects on annual ryegrass, intermediate ryegrass, tetraploid ryegrass, and perennial ryegrass and found that the timing and duration of traffic had less effect on perennial ryegrass as compared with the other ryegrasses. Data regarding comparative performance of turf-type annual ryegrass and perennial ryegrass cultivars would be useful for guiding more appropriate overseeding species selection.

Turfgrass colorants have become more widely used as an alternative to winter overseeding in recent years, particularly on warmseason golf course greens, tees, and fairways (Hartwiger and O'Brien, 2013; Van Dam and Kurtz, 1971) as well as athletic fields (Miller and Pinnix, 2014). The rise in colorant use may be partially related to water conservation efforts as well as reduced operation budgets. The cost of colorant application has been shown to be two to three times less than overseeding (Carson, 2004; Liu et al., 2007). Some turf managers have reported more rapid and consistent spring green-up due to colorant application, likely a result of elevated canopy temperatures of coloranttreated turf during the early spring green-up period (Liu et al., 2007; Long et al., 2005;

Shearman and Beard, 1975; Shearman et al., of overseeded turf requires regular irrigation or precipitation, and therefore has become more of a challenge in some areas of the country where municipal water restrictions may now limit winter irrigation to once per 7 to $14 \mathrm{~d}$, or even prohibit winter overseeding
Table 1. Monthly reference evapotranspiration $\left(\mathrm{ET}_{\mathrm{o}}\right)$, precipitation, supplemental irrigation, solar radiation, and mean daily air temperature at the Texas A\&M University Turfgrass Field Laboratory in College Station, TX as reported by the Texas ET Network.

\begin{tabular}{|c|c|c|c|c|c|c|c|c|}
\hline & & November & December & January & February & March & April & May \\
\hline \multirow[t]{5}{*}{$\overline{\text { Year } 1^{z}}$} & $\mathrm{ET}_{\mathrm{o},}(\mathrm{cm})$ & 7.1 & 5.6 & 8.3 & 6.7 & 10.2 & 14.8 & 16.8 \\
\hline & Precipitation $(\mathrm{cm})$ & 11.2 & 2.9 & 3.5 & 2.7 & 3.8 & 3.0 & 21.0 \\
\hline & Irrigation $(\mathrm{cm})$ & 3.3 & 5.1 & 5.1 & 4.4 & 5.1 & 7.6 & 2.5 \\
\hline & Solar radiation $\left(\mathrm{MJ} \cdot \mathrm{m}^{-2}\right)$ & 9.4 & 8.0 & 10.6 & 10.3 & 13.7 & 18.4 & 19.6 \\
\hline & Mean temperature $\left({ }^{\circ} \mathrm{C}\right)$ & 13.1 & 8.9 & 8.3 & 11.4 & 13.3 & 19.4 & 22.5 \\
\hline \multirow[t]{5}{*}{ Year $2^{y}$} & $\mathrm{ET}_{\mathrm{o}}(\mathrm{cm})$ & 8.5 & 5.7 & 5.8 & 6.3 & 8.7 & 12.2 & 13.1 \\
\hline & Precipitation $(\mathrm{cm})$ & 13.9 & 6.7 & 8.1 & 1.9 & 8.4 & 12.5 & 13.8 \\
\hline & Irrigation $(\mathrm{cm})$ & 8.0 & 3.8 & 1.9 & 4.4 & 0.0 & 0.0 & 0.6 \\
\hline & Solar radiation $\left(\mathrm{MJ} \cdot \mathrm{m}^{-2}\right)$ & 10.7 & 7.6 & 11.3 & 11.8 & 14.1 & 15.2 & 15.1 \\
\hline & Mean Temperature $\left({ }^{\circ} \mathrm{C}\right)$ & 12.5 & 13.1 & 9.7 & 11.1 & 15.8 & 21.1 & 23.6 \\
\hline
\end{tabular}

${ }^{2, y}$ Year 1 and 2 experiments were initiated on 10 Oct. 2013 and 15 Oct. 2014, respectively and lasted 7 months. 
Table 2. Analysis of variance for the effects of winter overseeding and colorant treatments (treatments) and traffic on 'Tifway' bermudagrass during the study period at the Texas A\&M University Turfgrass Field Laboratory in College Station, TX.

\begin{tabular}{|c|c|c|c|c|c|c|c|c|c|c|c|c|}
\hline \multicolumn{13}{|c|}{$P$ values } \\
\hline & \multicolumn{2}{|c|}{ Percent green cover } & \multicolumn{2}{|c|}{ Volumetric water content } & \multicolumn{2}{|c|}{ Spring canopy temperatures } & \multicolumn{2}{|c|}{ Percent injury } & \multicolumn{2}{|c|}{ Gmax } & \multicolumn{2}{|c|}{ Percent active bermudagrass } \\
\hline & Year $1^{z}$ & Year $2^{y}$ & Year 1 & Year 2 & Year 1 & Year 2 & Year 1 & $\overline{\text { Year } 2}$ & Year 1 & Year 2 & Year 1 & Year 2 \\
\hline Date (D) & $* * *$ & $* * *$ & $* * *$ & $* * *$ & NS & NS & $* * *$ & $* * *$ & ns & $* * *$ & $* * *$ & $* * *$ \\
\hline Treatment $(\mathrm{T})$ & $* * *$ & $* * *$ & $* * *$ & NS & NS & NS & $* * *$ & $* * *$ & $* * *$ & $* * *$ & $* * *$ & $* * *$ \\
\hline Traffic (Tr) & $* * *$ & $* * *$ & $* * *$ & NS & - & - & NS & NS & $* * *$ & $* * *$ & $* * *$ & NS \\
\hline $\mathrm{D} \times \mathrm{T}$ & $* * *$ & $* * *$ & $* * *$ & NS & NS & NS & $* * *$ & $* * *$ & NS & $* * *$ & $* * *$ & NS \\
\hline $\mathrm{D} \times \mathrm{Tr}$ & NS & NS & NS & NS & - & - & - & - & NS & $* * *$ & $* * *$ & NS \\
\hline $\mathrm{T} \times \mathrm{Tr}$ & NS & NS & NS & NS & - & - & - & - & NS & $* * *$ & $*$ & NS \\
\hline $\mathrm{D} \times \mathrm{T} \times \mathrm{Tr}$ & NS & NS & NS & NS & - & - & - & - & NS & $* * *$ & - & NS \\
\hline
\end{tabular}

NS, *,**,*** Not significant, significant at $P \leq 0.05,0.01$, or 0.001 , respectively.

${ }^{\mathrm{z}, \mathrm{y}}$ Year 1 and 2 experiments were initiated on 10 Oct. 2013 and 15 Oct. 2014, respectively and lasted 7 months.

2005). While there are advantages to using colorants as an alternative to overseeding, there could also be disadvantages. Nonoverseeded warm-season turfgrass fields that are under heavy winter traffic may benefit more from overseeding due to the protection offered by the actively growing cool-season turfgrass. Significantly reduced quality of nonoverseeded dormant 'Midiron' bermudagrass $(C$. dactylon $\times C$. transvaalensis BurttDavy) during October and November was reported due to simulated winter traffic, with injury disrupting uniformity and delaying green-up (Deaton and Williams, 2010; Dunn et al., 1994; Thoms et al., 2011).

The objectives of this 2-year field study were to evaluate effects of winter treatments overseeding and colorant application on performance (green cover, surface hardness, and soil moisture attributes), turfgrass injury resulting from simulated traffic, and spring transition of 'Tifway' bermudagrass under a 1-day per week irrigation schedule.

\section{Materials and Methods}

This research was conducted at the Texas A\&M University Research Turfgrass Field Laboratory in College Station, TX. The experiment was initiated on 10 Oct. 2013 (hereafter referred to as "year 1") and repeated on 15 Oct. 2014 (hereafter referred to as "year 2"), with each experiment lasting 7 months. For each year of the study, separate plots of established 'Tifway' bermudagrass were used. Soils for both study sites were characterized as a Booneville series (fine, smectitic, thermic, and chromic vertic Albaqualf). On the basis of physical analysis of the $0-15 \mathrm{~cm}$ soil depth, the topsoil at the year 1 site was characterized as a sandy loam (79\% sand, $12 \%$ silt, and $9 \%$ clay) with $\mathrm{pH} 9.7$, whereas the year 2 site was characterized as a sand ( $89 \%$ sand, $8 \%$ silt, and 3\% clay) with $\mathrm{pH}$ 8.9. At both sites, the A horizon topsoil varied from a depth of 10-30 cm, and lies atop a heavy clay $\mathrm{B}$ horizon subsoil. Soil tests indicated sufficient levels of all micro and macronutrients at both sites.

The study was arranged as a randomized complete block design with split plots and four replicate plots per treatment. Main plots $(1.5 \mathrm{~m} \times 1.5 \mathrm{~m})$ consisted of 1$)$ untreated bermudagrass, 2) colorant-treated bermudagrass, 3) perennial ryegrass overseeded bermudagrass,
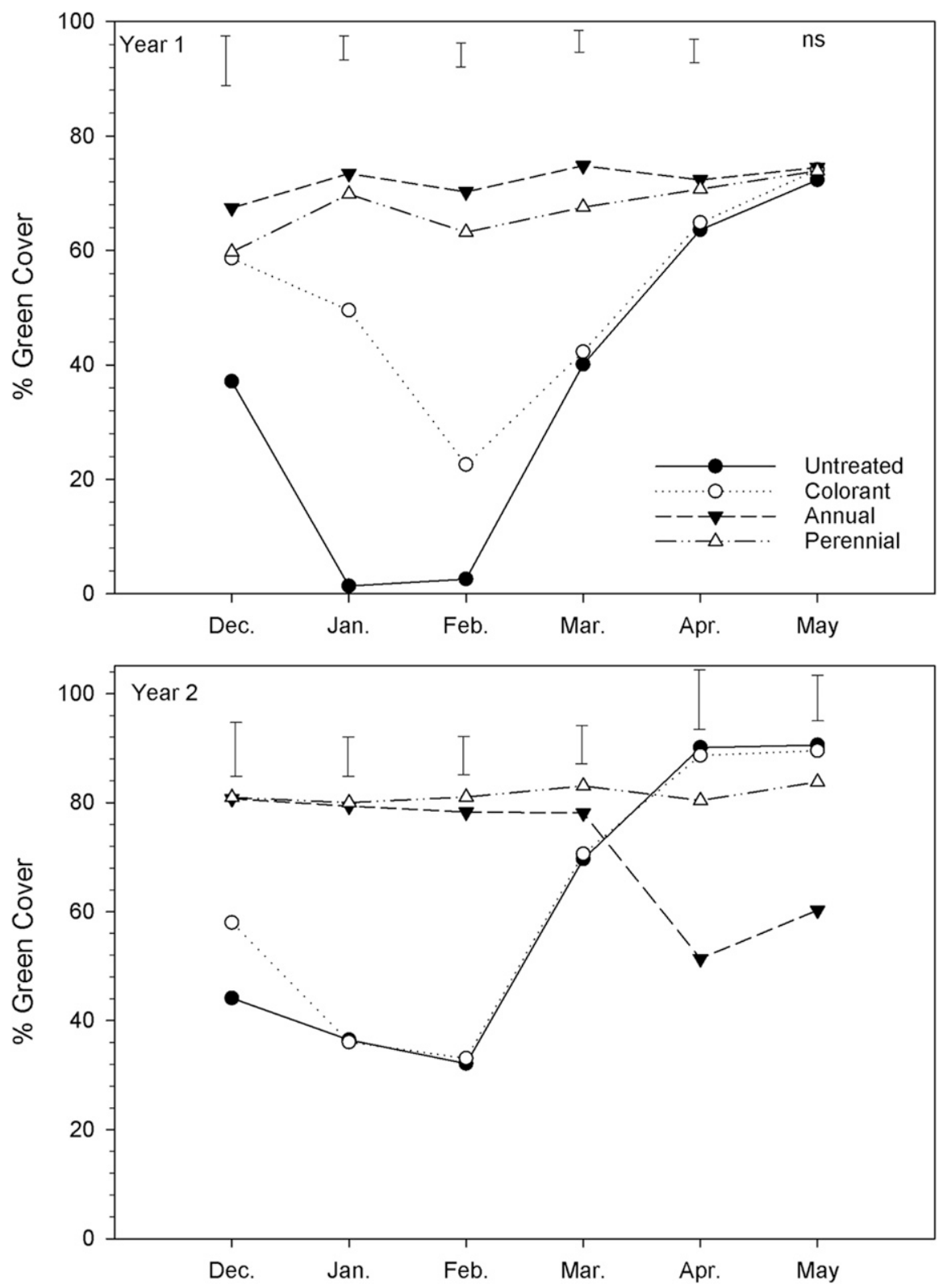

Fig. 1. Percent green cover as influenced by treatments for years 1 (top) and 2 (bottom). Data are pooled across traffic levels. Error bars denote differences between treatments based on Fisher's least significant difference (0.05).

and 4) turf-type annual ryegrass overseeded bermudagrass. Untreated bermudagrass entered shoot dormancy in early December frosts each year, with some active green shoots visible deep within the base of the canopy throughout the winter months. Coloranttreated bermudagrass received a single application of Green Lawnger turf colorant (BASF, 
Research Triangle Park, NC) before dormancy, on 2 Dec. of year 1 and 28 Nov. of year 2 using a $\mathrm{CO}_{2}$-powered backpack sprayer equipped with XR Teejet 8002VS nozzles (Spraying System Co., Wheaton, IL) and spray pressure of 40 psi. The sprayer was calibrated to deliver $561 \mathrm{~L} \cdot \mathrm{ha}^{-1}$ and a 7:1 $\mathrm{H}_{2} \mathrm{O}$ to colorant dilution was used. Because the product use recommendations indicate that fall applications to dormant bermudagrass turf should last 10-14 weeks (BASF Green Lawnger Technical Bulletin, 2013), and spring green-up usually occurs by mid-March in this region, only a single fall application of Green Lawnger was made in this study. However, a parallel study involving multiple rates and repeated applications of Green Lawnger during the winter dormancy period was also conducted simultaneously (Hargey et al., 2015).

Overseeded treatments were seeded 10 Oct. of year 1 and 15 Oct. of year 2. Before overseeding, bermudagrass plots were mowed to their maintenance height of $2.5 \mathrm{~cm}$. Perennial ryegrass plots were seeded using 'Futura 2000 ' perennial ryegrass (three-way blend of $34.45 \%$ 'Esquire', 30.81\% 'Greenway', and $35.05 \%$ 'Mercitwo' perennial ryegrass) (Pickseed, Tangent, OR), whereas annual ryegrass plots were seeded using 'Panterra V' annual ryegrass blend (two-way blend of $64.71 \%$ 'Panterra' and 34.85\% 'Panterra V' annual ryegrass) (Barenbrug USA, Tangent, OR). Plots of both species were overseeded via hand shaker jars at a rate of $49 \mathrm{~g} \cdot \mathrm{m}^{-2}$. A 290-5 $\left(\mathrm{N}-\mathrm{P}_{2} \mathrm{O}_{5}-\mathrm{K}_{2} \mathrm{O}\right)$ granular fertilizer (StaGreen All Season Lawn Fertilizer; Infinity Lawn and Garden, Milan, IL) was applied to all treatments at the time of overseeding using a broadcast spreader delivering a $\mathrm{N}$ rate of $4.9 \mathrm{~g} \cdot \mathrm{m}^{-2}$. The fertilizer was again applied 2 and 4 months after overseeding, resulting in a total $\mathrm{N}$ rate of $14.7 \mathrm{~g} \cdot \mathrm{m}^{-2}$ applied to the study area during the 7-month period.

Newly seeded plots were established under well-watered conditions during the initial $30 \mathrm{~d}$ of each year (mid-October through midNovember). During this time, all treatments received $6 \mathrm{~mm}$ irrigation 5 to $7 \mathrm{~d}$ weekly. After the 30-day establishment period, all plots including those treated with colorant, received $2 \mathrm{~cm}$ irrigation weekly. This irrigation amount was estimated to recharge the 0 to $15 \mathrm{~cm}$ soil depth root zone to field capacity. Weekly irrigation amounts were adjusted to account for any rainfall events of $2 \mathrm{~cm}$ or less received during the prior 7-day period. As such, if rainfall exceeded $2 \mathrm{~cm}$ during the 7-day period then the plots did not receive irrigation. Weather data including Penman-Monteith reference evapotranspiration $\left(\mathrm{ET}_{\mathrm{o}}\right)$, precipitation, air temperature, and solar radiation were monitored via an onsite weather station (Campbell Scientific, Logan, UT) connected to the Texas ET Network (texaset.tamu.edu). Plots were mowed weekly during the study at $3.2 \mathrm{~cm}$ using a rotary walk mower with clippings removed.

After the 30-day establishment period, main plots were subdivided into two sub plots receiving traffic levels of 0 or 4 passes weekly. Traffic was provided using a Cady

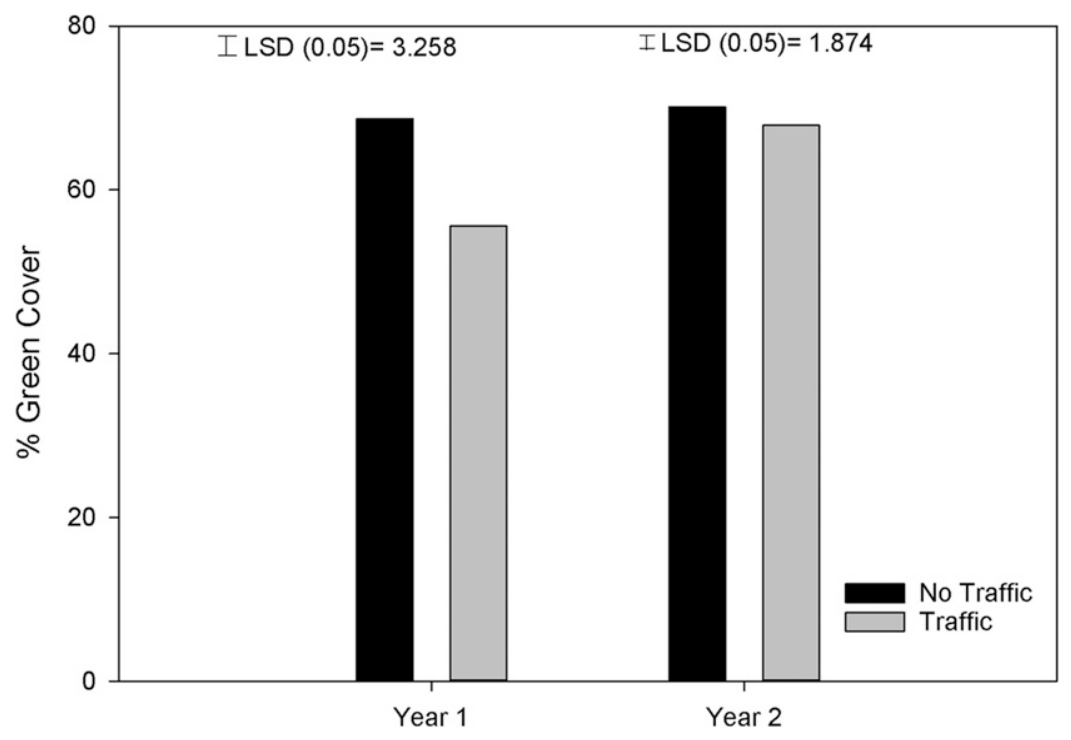

Fig. 2. Effect of traffic on percent green cover for years 1 and 2. Data are pooled across winter treatments. Error bars denote differences between treatments based on Fisher's least significant difference [LSD (0.05)].

Traffic Simulator (Henderson et al., 2005) equipped with rubber football cleats and operated in the forward direction. Traffic was applied immediately following each weekly mowing event throughout the final 6 months of each study. When rainfall occurred less than $24 \mathrm{~h}$ before a scheduled traffic event, trafficking was delayed by $24 \mathrm{~h}$. For reference, two passes with the Cady Traffic Simulator has been reported to simulate the amount of injury equivalent to one NCAA football game (Henderson et al., 2005).

Evaluation of treatments. Percent green cover was evaluated monthly for each treatment during the study using a digital camera (Canon PowerShot SX-170 IS; Canon, Tokyo, Japan) mounted on a metal $0.6 \mathrm{~m} \times 0.6 \mathrm{~m} \times$ $0.6 \mathrm{~m}$ cube light-box equipped with four compact fluorescent bulbs. Digital images were taken in the center of the plots $2 \mathrm{~d}$ following mowing and traffic application from December through May during the study. Images were analyzed for percent green cover using SigmaScan Pro (Systat Software, Inc., San Jose, CA) with hue and saturation settings of 45 to 120 and 0 to 100 , respectively (Karcher and Richardson, 2003, 2005; Richardson et al., 2001). Green cover levels equal to or exceeding $50 \%$ were deemed acceptable, while ratings below $50 \%$ were deemed unacceptable.

Visual assessment of percent turfgrass injury from simulated traffic was also recorded monthly in trafficked plots, $2 \mathrm{~d}$ following mowing and traffic application. Evaluations were adapted from the method described previously by Shearman and Beard (1975) where a rating of $0 \%$ indicated no injury, whereas $100 \%$ indicated bare soil was exposed and only stems remained in the plots. Intermediate ratings were as follows: $25 \%=$ $25 \%$ of leaf blades were shredded from sheaths, $50 \%=50 \%$ of leaf blades were shredded from sheaths and $75 \%=75 \%$ of leaf blades were shredded from sheaths with some exposed soil.
Percentage of actively growing bermudagrass was estimated in April and May of each year. Estimates were based on the method previously described by Dunn et al. (1994), and were based on a visual estimation of the percent of green, actively growing bermudagrass evident in plots relative to dormant, straw-colored bermudagrass, overseeded ryegrass, or bare soil.

Soil VWC within the $0-5 \mathrm{~cm}$ depth was measured monthly using a soil moisture meter (Fieldscout TDR 300; Spectrum Technologies, Inc., Aurora, IL). Measurements were taken between 1-2 d before irrigation events and were obtained within both trafficked and untrafficked subplots. Canopy temperatures were measured during cloudless afternoon periods using a handheld IR thermometer (Spectrum Technologies, Inc.), from a distance of $92 \mathrm{~cm}$ above the soil surface.

Surface hardness readings (Gmax) were collected monthly within all treatments using a $2.25 \mathrm{~kg}$ Clegg impact soil tester (SD Instrumentation, Bath, England), which provides a measure of impact absorption (Rogers and Waddington, 1992). Gmax is defined as the ratio of maximum negative acceleration on impact in units of gravities to the acceleration due to gravity. Gmax measurements were taken $2 \mathrm{~d}$ after simulated traffic was applied to plots. During measurement events, three Gmax readings were obtained within each sub plot. For each reading, two drops were made in a single spot, with Gmax for the second drop being recorded. These three Gmax values were then averaged for each plot.

Data analysis. Data for each parameter were subjected to analysis of variance using the general linear model, univariate test procedure in SPSS ver. 21.0 (IBM Corp, Armonk, NY) to determine statistical significance of the results. Year $\times$ treatment effect interactions were significant, therefore years 
were analyzed separately. Mean separation procedures were performed using Fisher's protected least significance difference test at the $P \leq 0.05$ level.

\section{Results and Discussion}

Weather data. The first year of the study was characterized by higher evaporative demand, less precipitation, higher monthly solar radiation, and lower mean air temperatures relative to year 2 (Table 1 ). $\mathrm{ET}_{\mathrm{o}}$ increased from $5.6 \mathrm{~cm}$ in December to a maximum of $16.8 \mathrm{~cm}$ in May of year 1 , and from $5.7 \mathrm{~cm}$ in December to a maximum of $13.1 \mathrm{~cm}$ in year 2 . Solar radiation increased from $8.0 \mathrm{MJ} \cdot \mathrm{m}^{-2}$ in December to $19.6 \mathrm{MJ} \cdot \mathrm{m}^{-2}$ in May of year 1 , and from 7.6 MJ.m ${ }^{-2}$ in December to $15.1 \mathrm{MJ} \cdot \mathrm{m}^{-2}$ in May of year 2 . While total precipitation for the 6-month period was greater in year 2, May of year 1 was considerably wetter than that of year 2 ( 21.0 vs. $13.8 \mathrm{~cm}$, respectively). Nighttime temperatures were lower during year 1 , which contributed to a greater degree of visible shoot dormancy in plots compared to year 2 (data not shown).

Percent green cover. There was also a significant date $\times$ treatment interaction on percent green cover during both years (Table 2). Whereas untreated bermudagrass fell to $0 \%$ green cover by January in year 1 , it declined to only $\approx 30 \%$ green cover in February of year 2 , as some green shoots persisted through the winter months and were visible deep within the canopy. This was likely due to the relatively higher $\left(\approx 1-4{ }^{\circ} \mathrm{C}\right)$ mean daily and nighttime air temperatures from December to February period of year 2, which may have prevented onset of full shoot dormancy (Table 1). With the exception of December of year 1, overseeded plots maintained consistently higher percent green cover compared with nonoverseeded and coloranttreated plots from December through March of both years (Fig. 1). From December through March, overseeding resulted in $\approx 65 \%$ to $80 \%$ green cover in years 1 and 2 , respectively. Percent green cover of perennial ryegrass remained stable through the entire period during both years, but annual ryegrass declined by $50 \%$ in April of year 2 due to excessive growth and scalping resulting from weekly mowing during the excessively cloudy and rainy March and April months. Colorant application resulted in $60 \%$ green cover ratings for December of both years. In year 1, the effects of the colorant application lasted through February; however, in year 2, they only remained through December. This is likely due to the considerably higher (more than $200 \%$ higher) rainfall amounts received in December and January of year 2 compared with year 1. By March of year 1 and January of year 2, there were no differences in percent green cover remaining between untreated and colorant-treated plots. By May of year 1, all treatments exhibited similar levels $(\approx 70 \%)$ of green cover; however, at the conclusion of year 2, annual ryegrass green cover declined by $25 \%$ compared with all other treatments, which were exhibiting between $80 \%$ and $90 \%$ green cover levels.

A significant traffic main effect on percent green cover was also detected during both years (Table 2). When averaging across all treatments, traffic resulted in a $\approx 15 \%$ decrease in percent green cover in year 1 , but only a $\approx 3 \%$ decrease in year 2 (Fig. 2). It is likely that differences by year with respect to traffic effects on percent green cover may have been attributable to bermudagrass achieving complete shoot dormancy in year 1 , but retaining $>30 \%$ green cover through most of year 2. This minimal active growth of bermudagrass may have aided in offsetting the traffic effects. Furthermore, while cloudier conditions prevailed, the slightly elevated temperatures of year 2 were also possibly more conducive to growth of the overseeded ryegrass. Haselbauer et al. (2012) evaluated effects of repeated autumn simulated traffic on percent green cover of five experimental bermudagrasses as well as cultivars Tifway, Tifsport, and TifGrand bermudagrass in Tennessee. By mid-November (after 20 simulated traffic events) of their study, percent green cover of nonoverseeded plots ranged from $14 \%$ to $34 \%$ after year 1 , but ranged from $58 \%$ to $79 \%$ in year 2 . The increased cover observed was attributed to $\approx 5{ }^{\circ} \mathrm{C}$ higher air temperatures in year 2 , which promoted greater levels of bermudagrass recovery during the 2 nd year. Similarly, Thoms et al. (2011) reported that percent green cover of Tifway bermudagrass decreased from $95 \%$ to $63 \%$ after 17 autumn traffic events (August through November) in Tennessee. While there are a number of reports evaluating
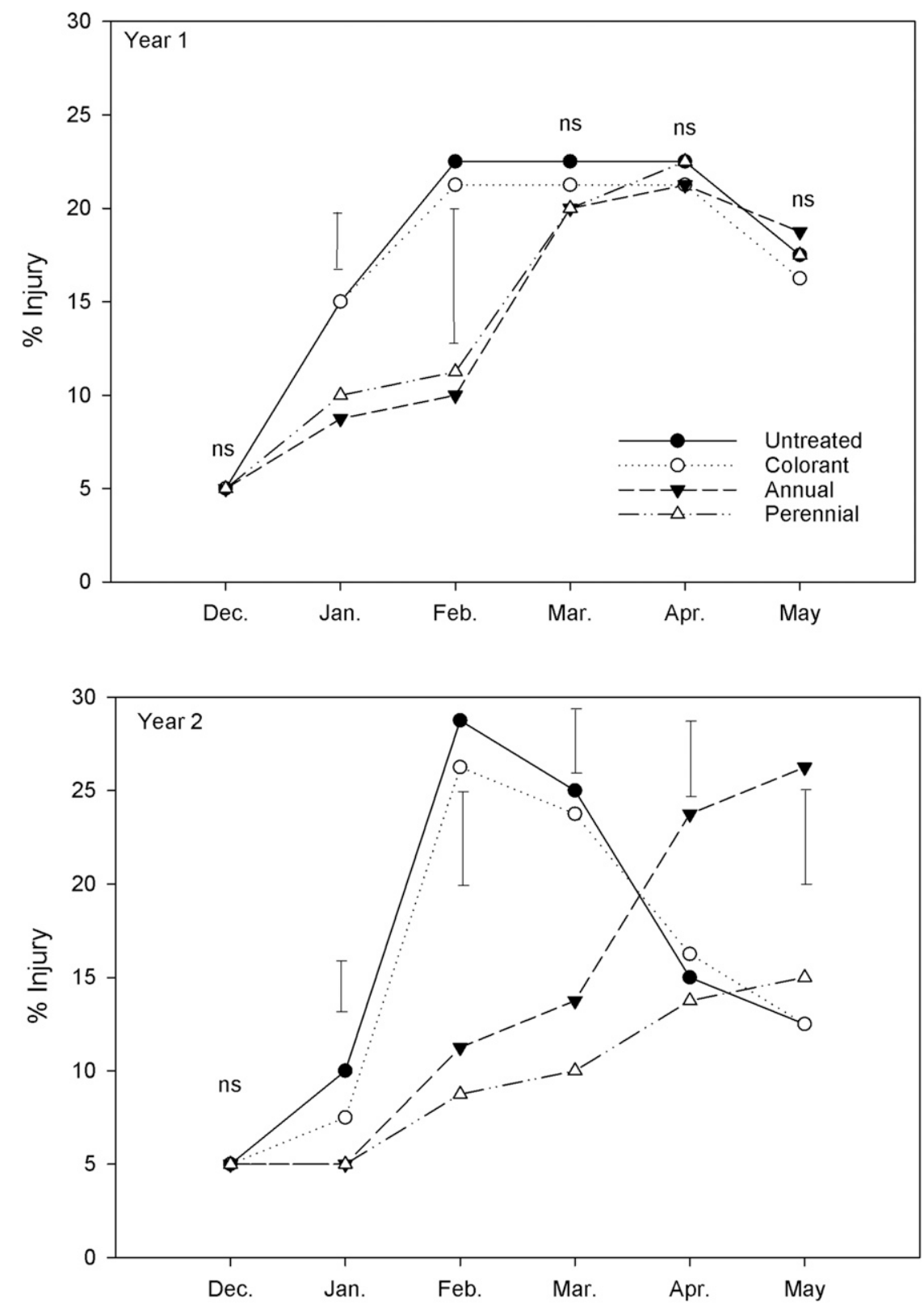

Fig. 3. Percent visual injury by month for years 1 (top) and 2 (bottom) as affected by winter treatments. Data are for trafficked plots. Error bars denote differences between treatments based on Fisher's least significant difference $(0.05)$. 
traffic tolerance of bermudagrass during summer and autumn months, there are not much published data regarding the effects of repeated winter traffic on dormant bermudagrass.

Percent visual turfgrass injury. A date $\times$ treatment interaction for percent visual turfgrass injury occurred due to weekly traffic applications during both years 1 and 2 (Table 2; Fig. 3). Percent turfgrass injury peaked at $22 \%$ for all treatments in April of year 1 before recovery taking place during May. For year 2, peak injury of $28 \%$ was noted for untreated and colorant-treated plots in February before recovery. Not surprisingly, untreated and colorant-treated plots exhibited the greatest levels of visual turfgrass injury from January through March rating dates, with no differences noted between the two treatments on any rating date (Fig. 3). Visual turfgrass injury of annual and perennial ryegrass-overseeded plots was significantly lower than colorant-treated or untreated plots for January through March periods in both years. Injury of overseeded plots gradually increased from December through April of year 1 and through May of year 2. Although no injury differences between the ryegrass species were observed in year 1, annual ryegrass-overseeded plots exhibited significantly greater injury relative to perennial ryegrass-overseeded plots in year 2 (Fig. 3). The lower injury levels observed in perennial vs. annual ryegrass are consistent with findings of Shearman and Beard (1975), who evaluated wear tolerance of seven different winter overseeded cool-season grasses in bermudagrass and reported wear tolerance of 'Manhattan' perennial ryegrass to be superior to annual ryegrass, kentucky bluegrass (Poa pratensis L.), tall fescue (Festuca arundinacea Schreb.), red fescue (Festuca rubra L.), chewing fescue (F. rubra var. commutata Gaud.), and rough bluegrass (Poa trivialis L.). Similar results from comparisons of cool-season turfgrass traffic tolerance have been reported by Bourgoin and Mansat (1979), Canaway (1978), and Carrow and Petrovic (1992). While limited published data are available comparing traffic tolerance of colorant-treated and untreated dormant bermudagrass, the similar injury levels observed throughout the study period suggest that colorant application neither increased nor decreased bermudagrass traffic tolerance.

Percent active bermudagrass. A significant treatment $\times$ traffic interaction on percent active bermudagrass occurred in year 1 but not in year 2 (Table 2; Fig. 4). As such, overseeding of either species resulted in a significant $(\approx 40 \%$ to $50 \%)$ decrease in visible active bermudagrass in plots in year 1 compared with nonoverseeded plots (Fig. 4). Percent active bermudagrass was also similar between annual and perennial ryegrass overseeded plots. Furthermore, whereas traffic reduced active bermudagrass by $\approx 10 \%$ in colorant-treated and nonoverseeded plots, it had no effect on percent active bermudagrass of overseeded plots. Interestingly, although there have been anec- dotal observations of enhanced spring bermudagrass growth due to fall colorant application, we observed no significant differences between colorant-treated and untreated plots in terms of April and May percent active bermudagrass levels. Spring canopy temperature measurements taken during March, April, and May also did not significantly differ between colorant-treated and untreated plots (Table 2). These results could be due to the single application of Green Lawnger wearing off before the conclusion of the study period. For year 2, percent active bermudagrass was affected only by treatment, with no effect or interaction due to traffic observed (Table 2; Fig. 5). Consistent with year 1 , overseeding significantly reduced percent active bermudagrass in plots; however, reductions were again similar between annual vs. perennial overseed stands.

Our results are in agreement with those of Cockerham et al. (1990) who reported $42 \%$ and $61 \%$ reductions (untrafficked and trafficked plots, respectively) in bermudagrass transition due to overseeding of perennial ryegrass. It should be noted that percent active bermudagrass ratings in their work was observed at the conclusion of the study following chemical transition of perennial ryegrass. However, our observation of bermudagrass transition differs somewhat with that of Cockerham et al. (1990), who reported similar amounts of bermudagrass in annual ryegrass-overseeded and nonoverseeded plots during spring transition evaluations. Richardson (2004) also compared spring transition of annual and perennial ryegrasses

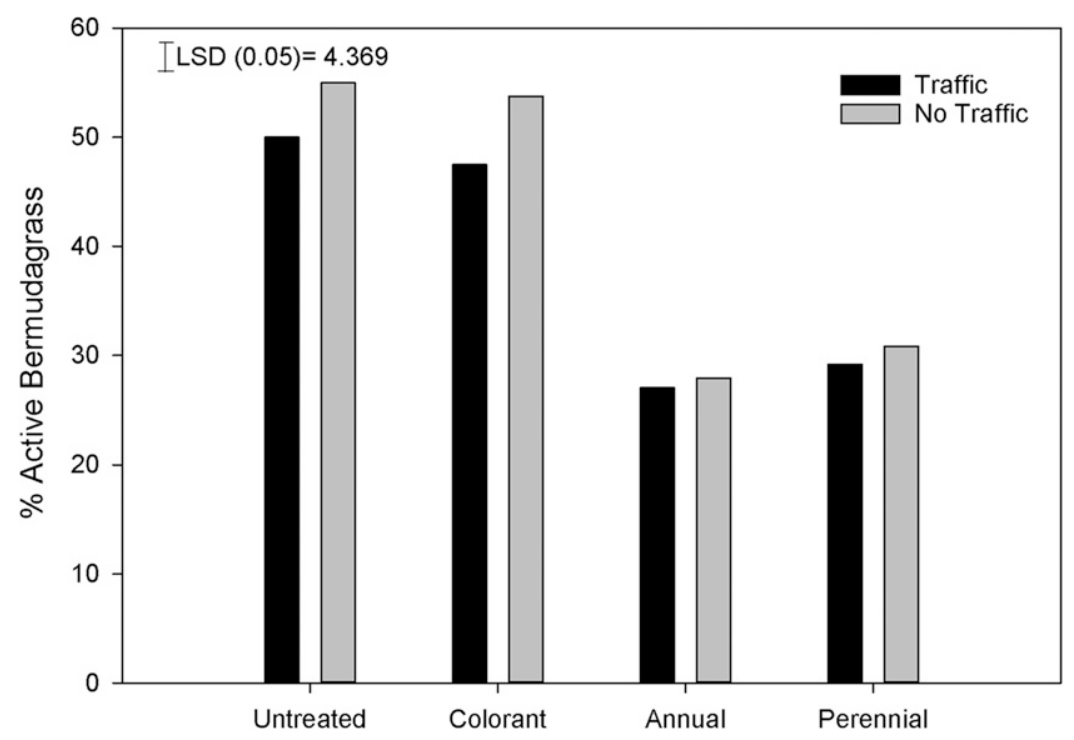

Fig. 4. Percent active bermudagrass as influenced by winter treatment and traffic for year 1 . Error bars denote differences between treatments based on Fisher's least significant difference [LSD (0.05)].

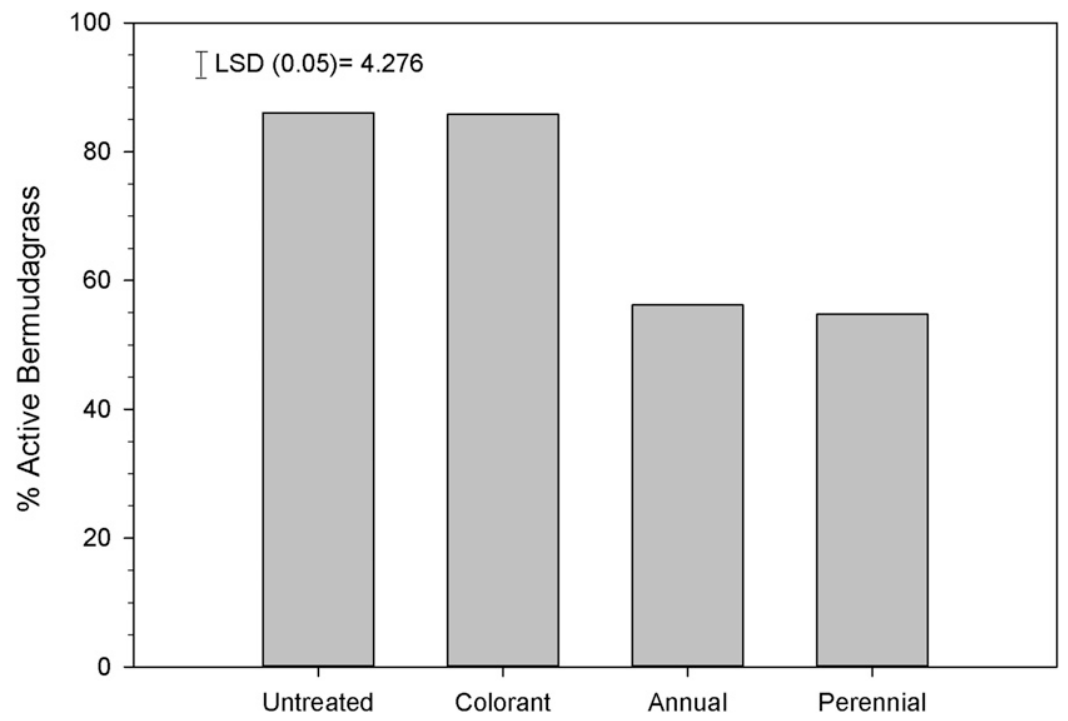

Fig. 5. Percent active bermudagrass as influenced by winter treatment for year 2. Data are pooled across traffic levels. Error bars denote differences between treatments based on Fisher's least significant difference [LSD (0.05)]. 
in Arkansas and reported that annual ryegrassoverseeded plots exhibited $46 \%$ and $55 \%$ ryegrass in late May, whereas perennial ryegrass-overseeded plots still had 95\% to $100 \%$ ryegrass. Differences between these studies could be due to our use of an improved turf-type annual ryegrass providing additional competition compared with the Fayetteville, AR trial as well as the high rainfall and elevated spring temperatures in our study.

Volumetric water content. A significant date $\times$ treatment interaction, date, and traffic main effect were detected for soil VWC in year 1. However, only date significantly affected VWC during year 2 (Table 2; Fig. 6). During December of year 1, no differences in VWC were detected among treatments, with all plots exhibiting VWC of $\approx 38 \%$. On subsequent rating dates, significant differences in VWC occurred among the treatments. For January through May ratings, overseeded treatments exhibited from $\approx 2 \%$ to $6 \%$ lower VWC compared with untreated and colorant-treated plots. Although the slightly lower VWC within annual ryegrass plots relative to perennial ryegrass would suggest higher ET rates, these differences were minimal and not significantly different. No differences occurred between coloranttreated and untreated plots for any month. Water consumption of bermudagrass has been reported to range from 2.5 to $7.5 \mathrm{~mm}$ per day during summer months (Beard, 1972); however, the influence of bermudagrass ET on soil moisture during these winter months was likely negligible with the exception of the May rating date. Although there are limited published data comparing water requirements or ET rates of annual and perennial ryegrass cultivars, levels of irrigation/ precipitation received during this study period were sufficient to support acceptable levels of turf quality for both species through the duration of the winter growth period until onset of warmer May temperatures (data not shown). Had lower than normal amounts of precipitation occurred during the study period, it is likely that higher levels of stress may have occurred under this 1-day per week irrigation.

A significant effect of traffic on VWC was also observed during year 1 (Table 2). Volumetric water content of trafficked plots was decreased relative to untrafficked plots (34.9\% vs. $37.6 \%$ for trafficked and untrafficked, respectively). While similar effects were not observed in year 2, trafficked plots had slightly lower VWC compared with untrafficked plots $(30.1 \%$ vs. $30.5 \%$ for trafficked and untrafficked, respectively). It is likely that these differences could be attributed to compaction caused by the simulated traffic. Compaction causes changes in soil such as altered pore size distribution and increased bulk density (Boufford and Carrow, 1980; Carrow, 1980). Agnew and Carrow (1985) also reported decreased soil moisture content with increasing traffic within the $0-3 \mathrm{~cm}$ soil depth, reporting soil moisture decreases of $8 \%$ and $12 \%$ for short- and long-term traffic, respectively. Similar findings have also been reported by O'Neil and Carrow (1983). It is also possible that decreased density of trafficked plots may have led to greater soil evaporation relative to untrafficked plots. Both elevated precipitation amounts as well as the sandier-textured soils used in year 2 may have limited the capacity to once again detect similar treatment differences.

Surface hardness (Gmax). Treatment and traffic main effects were detected for surface hardness in each year of the study. Year 1 Gmax measurements ranged from 60 to 72 , whereas year 2 measurements ranged from only 50 to 67 (Figs. 7 and 8). Differences between years could have been impacted by soil textural differences between the two study sites, as well as higher soil moisture levels during year 2. For year 1, overseeding reduced surface hardness relative to untreated and colorant-treated plots $(\approx 60$ vs. 70 for overseeded vs. untreated/coloranttreated, respectively); however, no differences were noted between annual vs. perennial ryegrass or between untreated vs. coloranttreated plots. In year 1, Gmax was higher in trafficked vs. untrafficked plots (74 vs. 61 , respectively), regardless of treatment (data not shown). During the course of year 2, surface hardness of trafficked treatments increased monthly on overseeded plots, resulting in an increase of $19 \%$ for annual ryegrass and $5 \%$ for perennial ryegrass by the final May rating date (data not shown). Untreated and colorant-treated plots exhibited peak Gmax in March of year 2, just before bermudagrass growth resumed in

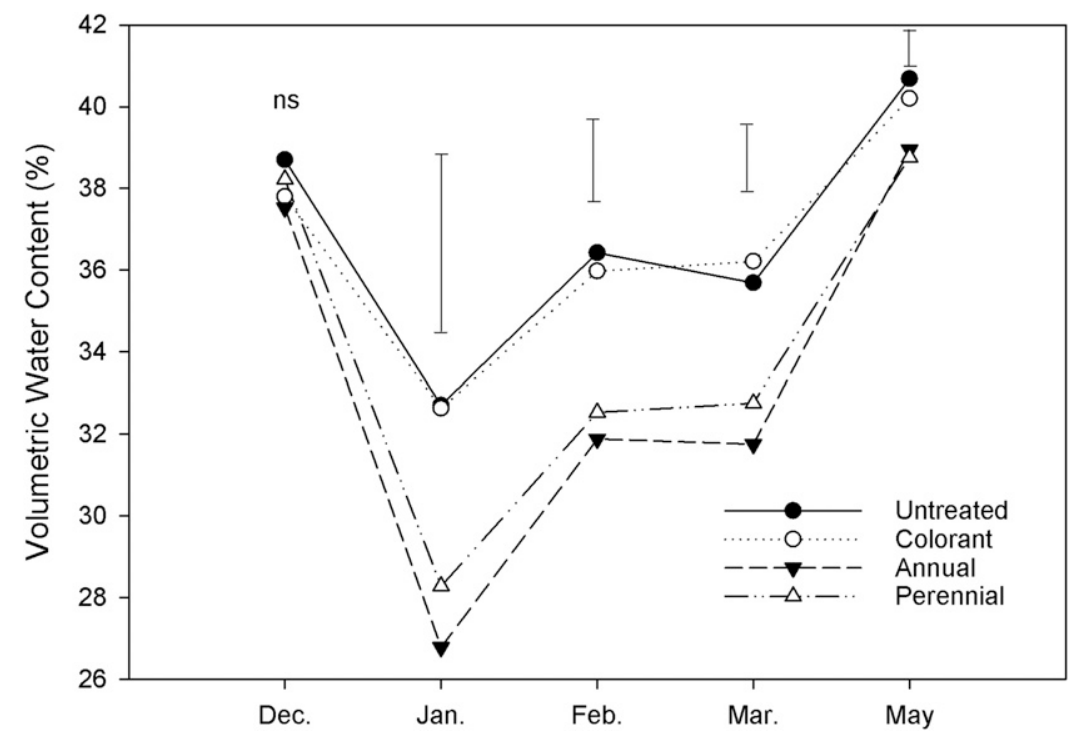

Fig. 6. Soil volumetric water content by month for year 1. Data are pooled across traffic treatments. Error bars denote differences between treatments based on Fisher's least significant difference $(0.05)$.

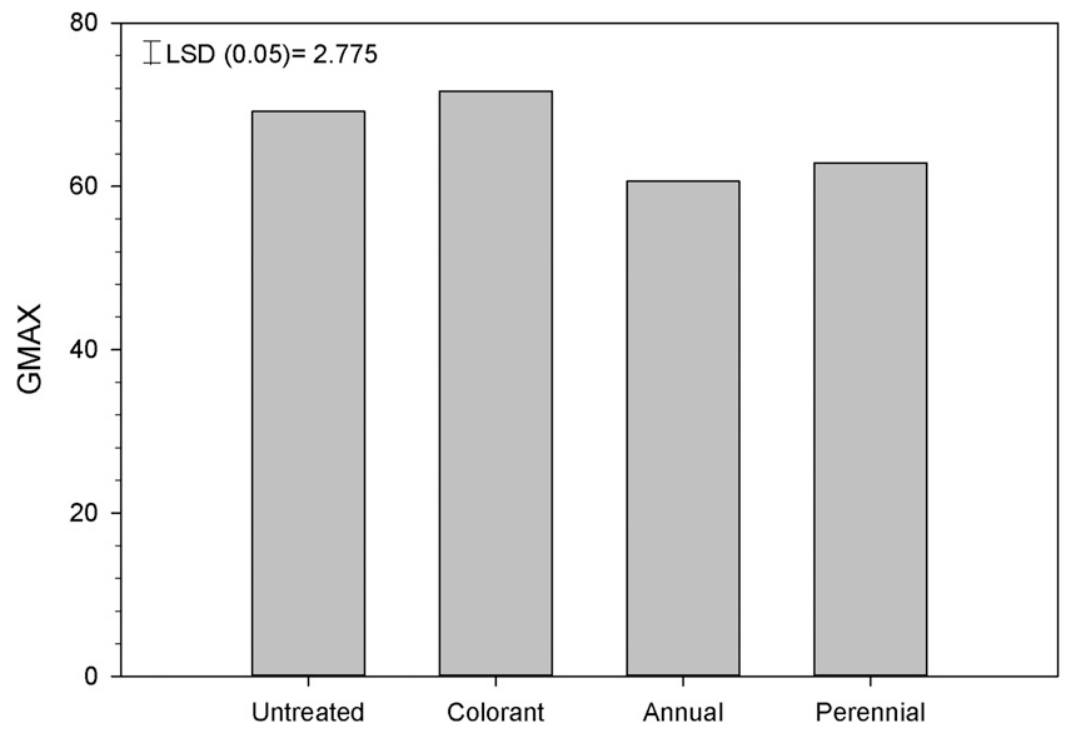

Fig. 7. Surface hardness (Gmax) as affected by winter treatment for year 1. Data are pooled across traffic levels. Error bars denote differences between treatments based on Fisher's least significant difference [LSD (0.05)]. 


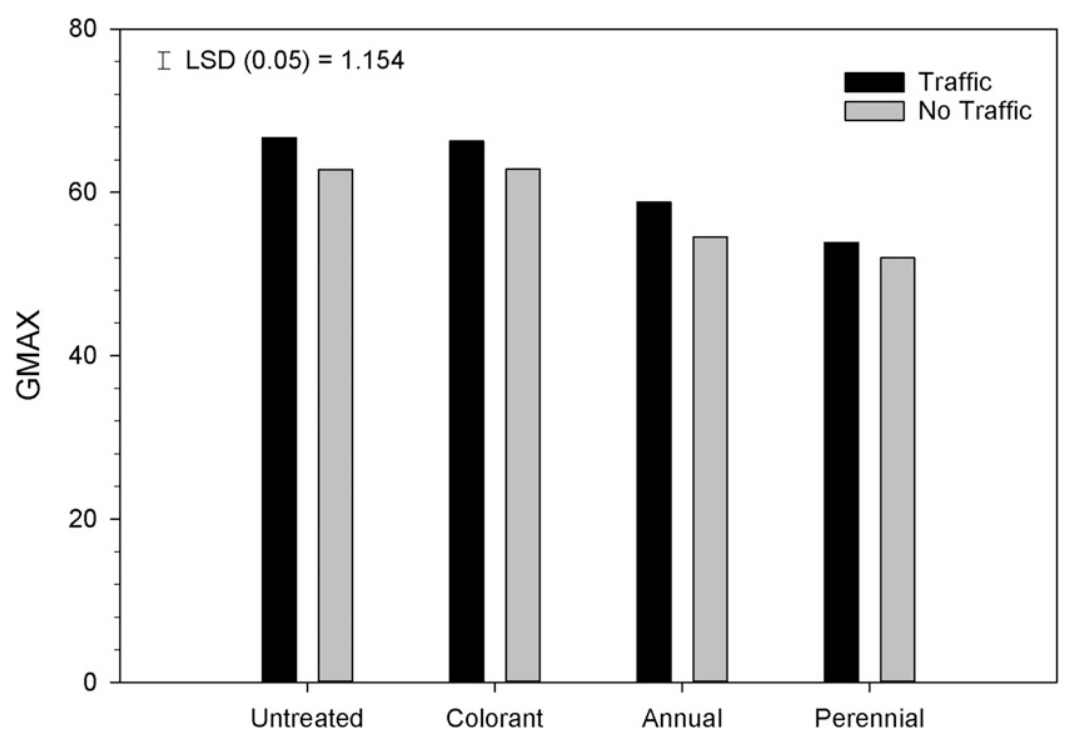

Fig. 8. Surface hardness (Gmax) as affected by winter treatment and traffic for year 2. Error bars denote differences between treatments based on Fisher's least significant difference [LSD (0.05)].

spring. Traffic significantly increased Gmax across all treatments in year 2; however, perennial ryegrass showed the least change in surface hardness from traffic (Fig. 7). Dunn et al. (1994) reported similar to slightly elevated Gmax measurements in nonoverseeded compared with perennial ryegrassoverseeded bermudagrass plots in ratings taken during early summer in a 2-year Missouri study (51 vs. 49 and 37 vs. 37 for nonoverseeded and overseeded plots, respectively). These readings are somewhat lower than those reported in our study, likely due to their measurements being taken during summer months, when active bermudagrass growth had resumed. Dunn et al. (1994) also reported $36 \%$ to $74 \%$ increases in surface hardness of bermudagrass resulting from traffic in overseeded and nonoverseeded plots, respectively. The greater increase in Gmax observed in their study could be a result of a substantially greater number of weekly traffic simulator passes (10 passes three times weekly) compared with the 4 weekly passes provided in the current study. Stoloniferous grasses such as bermudagrass tend to produce greater amounts of thatch and biomass compared with bunch-type turfgrasses such as perennial ryegrass, and therefore may provide more cushion to the impact of the Clegg tester (Waddington, 1990). Canaway et al. (1990) has suggested that Gmax ratings for athletic turf should ideally fall between 20 and 80 while acceptable ratings could range from 10 to 100 . Although all treatments in our study exhibited Gmax measurements of less than 100 , it is possible that more intensive traffic may have produced unacceptable levels. While we are not aware of any existing standards for youth or recreational athletic fields, the National Football League field testing program currently requires playing surface hardness of both natural and synthetic turf fields to be lower than 100 Gmax (Sports Turf Managers Association, 2015).

\section{Conclusions}

Given the need for increased urban water conservation and reduced operating budgets, southern and transition zone turf managers will need to continue to evaluate options for and alternatives to winter overseeding of trafficked, dormant warm-season turf. Improved "turf-type" annual ryegrasses may offer better turf quality relative to older cultivars; however, there is concern that they may be less tolerant of traffic or infrequent irrigation. Also, while use of turf colorants is an alternative that has seen growing adoption within golf and athletic turf management, the practice may not be practical for areas receiving greater amounts of wear from traffic. This research compared performance, tolerance to simulated traffic, and spring transition of Tifway bermudagrass treatments under a weekly supplemental irrigation schedule. On the basis of these results, both improved turf-type annual ryegrass and perennial ryegrass maintained acceptable levels $(60 \%$ to $80 \%$ ) of green cover during each year of the study. While tolerance to simulated traffic (four passes weekly) did not differ between the two species in year 1, the higher precipitation and cloud cover of year 2 may have contributed to greater injury levels within annual ryegrass in year 2 . In addition, residual benefits of fall colorant application were variable, extending into February of year 1 , but dissipating by late December of year 2. These results indicate that repeat applications are likely necessary to maintain color during winter months, with the number of applications depending on environmental conditions. Overseeding, regardless of species, reduced spring transition of bermudagrass by $40 \%$ to $50 \%$ compared with untreated and colorant-treated plots, with no stimulation of bermudagrass transition resulting from the single fall colorant application. Results of this study also demonstrate that environmental differences from season to season can impact the relative benefits derived from overseeding or colorant application.

\section{Literature Cited}

Agnew, M.L. and R.N. Carrow. 1985. Soil compaction and moisture stress preconditioning in Kentucky bluegrass. I. Soil aeration, water use, and root responses. Agron. J. 77:872-878.

BASF Green Lawnger Technical Bulletin. 2013. BASF Green Lawnger Turf Paint and Divot Mix Colorant. 23 Feb. 2016. <http://www. betterturf.basf.us/products/related-documents/ green-lawnger-technical-information-bulletin.pdf $>$.

Beard, J.B. 1972. Turfgrass: Science and culture. Prentice Hall, Englewood Cliffs, NJ.

Boufford, R.W. and R. Carrow. 1980. Effects of intense, short-term traffic on soil physical properties and turfgrass growth. Trans. Kans. Acad. Sci. 1903:78-85.

Bourgoin, B. and P. Mansat. 1979. Persistence of turfgrass species and cultivars. J. Sports Turf Res. Inst. 55:121-140.

Canaway, P. 1978. Trials of turfgrass wear tolerance and associated factors-a summary of progress 1975-1977. J. Sports Turf Res. Inst. 57:108-121.

Canaway, P.M., M.J. Bell, G. Holmes, and S.W. Baker. 1990. Standards for the playing quality of natural turf for association football, p. 2947. In: R.C. Schmidt et al. (ed.). Natural and artificial playing fields: Characteristics and safety features. STP 1073. American Society for Testing and Materials, Philadelphia, PA.

Carrow, R.N. 1980. Influence of soil compaction on three turfgrass species. Agron. J. 72:1038-1042.

Carrow, R.N. and A.M. Petrovic. 1992. Effects of traffic on turfgrasses, p. 285-330. In: D.V. Waddington, R.N. Carrow, and R.C. Shearman. (eds.). Turfgrass. Agronomy Monograph 32. ASA, CSSA, and SSSA, Madison, WI.

Carson, T. 2004. Overseed or paint? Golf Course Mgt. 72(12):22.

City of Allen, TX. 2015. Stage 2 water restrictions. 3 Sept. 2015. <http://allentx.swagit.com/play/ 08302011-155>.

Cockerham, S.T., V.A. Gibeault, J. Van Dam, and M.K. Leonard. 1990. Tolerance of several cool-season turfgrasses to simulated sports traffic, p. 85-95. In: Natural and artificial playing fields: Characteristics and safety features Proc. Symp. Charactersistics and Safety of Playing Surfaces (Artificial and Natural) for Field Sports, Pheonix, AZ. 6 Dec. 1988. ASTM, West Conshohocken, PA.

Deaton, M.T. and D.W. Williams. 2010. Overseeding and trinexapac-ethyl effects on tolerance to simulated traffic of four bermudagrass cultivars grown as a sand-based athletic field. HortTechnology 20:724-729.

Dunn, J.H., D.D. Minner, B.F. Fresenburg, and S.S. Bughrara. 1994. Bermudagrass and cool-season turfgrass mixtures: Response to simulated traffic. Agron. J. 86:10-16.

Hargey, D., C. Reynolds, B. Wherley, R. White, and J. Thomas. 2015. Overseeding and pigment impacts on bermudagrass spring transition. 2015 ASA-CSSA-SSSA International Annual Meetings Abstracts 418-24.

Hartwiger, C. and P. O’Brien. 2013. Fall greenup: Turf Colorants are redefining winter playing conditions. USGA Green Section Course Care. 3 Sept. 2015. <http://www.usag.org/ course-care/2013/09/fall-greenup-turf-colorantsare-redefining-winter-playing-conditions21474860082.html>.

Haselbauer, W.D., A.W. Thoms, J.C. Sorochan, J.T. Brosnan, B.M. Schwartz, and W.W. Hanna. 
2012. Evaluation of experimental bermudagrasses under simulated athletic field traffic with perennial ryegrass overseeding. HortTechnology 22:94-98.

Henderson, J.J., J.L. Lanovaz, J.N. Rogers, III, J.C. Sorochan, and J.T. Vanini. 2005. A new apparatus to simulate athletic field traffic: The Cady Traffic Simulator. Agron. J. 93:1153-1157.

Karcher, D.E. and M.D. Richardson. 2003. Quantifying turfgrass color using digital image analysis. Crop Sci. 43:943-951.

Karcher, D.E. and M.D. Richardson. 2005. Batch analysis of digital images to evaluate turfgrass characteristics. Crop Sci. 45:1536-1539.

Kopec, D. and K. Umeda. 2014. Overseeding winter grasses into bermudagrass turf. Univ. of Ariz. Ext. Bulletin. 23 Feb. 2016. <http://urf.arizona.edu/ Overseeding $\% 20$ winter $\% 20$ grasses $\% 20$ into $\%$ 20bermudagrass $\% 20$ turf $\% 20$ Aug $\% 202014 \%$ 20v3\%201tr.pdf>.

Liu, H., L.B. McCarty, C.M. Baldwin, W.G. Sarvis, and S.H. Long. 2007. Painting dormant bermudagrass putting greens. Golf Course Mgt. 75:86-91.

Long, S.H., H. Liu, L.B. McCarty, and J. Thackston. 2005. If it's winter, it must be time to put on a coat (of green paint). Turfgrass Trends 61:56-58.
Miller, G. and D. Pinnix. 2014. Green sports fields using turf colorants. Sports Turf Magazine Online. 3 Sept. 2015. http://sportsturfonline. com/2014/10/09/green-sports-fields-using-turfcolorants/.

Nelson, L., J. Crowder, and H. Pemberton. 2005. Performance and transition date of a turf-type annual ryegrass in comparison to perennial ryegrass and fine fescues. HortTechnology 15:304-308

O’Neil, K.J. and R.N. Carrow. 1983. Perennial ryegrass growth, water use, and soil aeration status under soil compaction. Agron. J. 75: 177-180.

Richardson, M.D. 2004. Morphology, turf quality, and heat tolerance of intermediate ryegrass. HortScience 39:170-173.

Richardson, M.D., D.E. Karcher, and L.C. Purcell. 2001. Quantifying turfgrass cover using digital image analysis. Crop Sci. 41:1884-1888.

Rogers, J.N. and D.V. Waddington. 1992. Impact absorption characteristics on turf and soil surfaces. Agron. J. 84:203-209.

San Antonio Water System. 2013. SAWS Conservation Ordinance. 3 Sept. 2015. <http://www.saws. org/Conservation/Ordinance/download.cfm>.

Shearman, R. and J. Beard. 1975. Turfgrass wear tolerance mechanisms: I. Wear tolerance of seven turfgrass species and quantitative methods for determining turfgrass wear injury. Agron. J. 67:208-211.

Shearman, R., L. Wit, S. Severmutlu, H. Budak, and R. Gaussoin. 2005. Colorant effects on dormant buffalograss turf performance. HortTechnology 15:244-246.

Sports Turf Managers Association. 2015. Field hardness testing. 21 Sept. 2015. <http://www. stma.org/sites/stma/files/STMA_Bulletins/ Field_Hardness\%20FINAL.pdf $>$.

Thoms, A.W., J.C. Sorochan, J.T. Brosnan, and T.J. Samples. 2011. Perennial ryegrass (L.) and grooming affect bermudagrass traffic tolerance. Crop Sci. 51:2204-2211.

Trappe, J.M., M.D. Richardson, and A.J. Patton. 2012. Species selection, pre-plant cultivation, and traffic affect overseeding establishment in bermudagrass turf. Agron. J. 104: 1130-1135

Van Dam, J. and K. Kurtz. 1971. A turfgrass colorant study. California Turfgrass Cult. 22: 26-28.

Waddington, D.V. 1990. Effects of management practices on impact absorption and shear resistance in natural turf. Natural and Artificial Playing Fields: Characteristics and Safety Features 1073:136. 